\title{
Capital-Market Liberalization, Globalization and the IMF
}

\author{
Joseph E. Stiglitz \\ $3 / 10 / 2004$
}

\section{MAJOR CONTROVERSY CONCERNING CAPITAL MARKET LIBERALIZATION}

- IMF TRIED TO CHANGE CHARTER TO FORCE COUNTRIES TO LIBERALIZE CAPITAL MARKETS

- US TRIED TO "FORCE" KOREA TO LIBERALIZE CAPITAL MARKETS IN 1993--SUCCEEDED 


\section{AT TIME, UNSUPPORTED BY THEORY OR EVIDENCE}

- CML DID NOT INCREASE GROWTH OR INVESTMENT(RODRIK)

- CML EXPOSED COUNTRIES TO GREATER RISK

Growth and capital account liberalization 1975-89 Rodrik (1998)

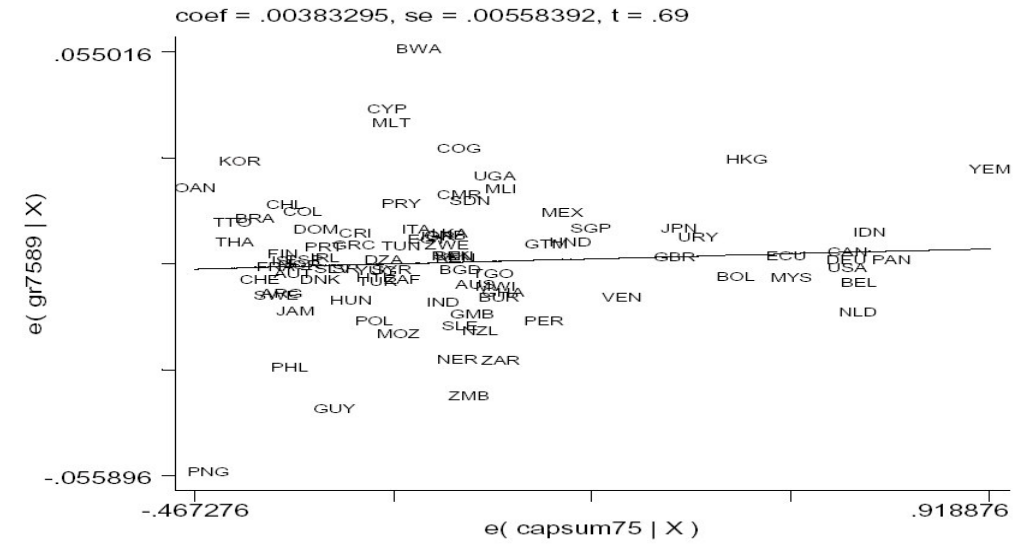

Figure 1: Partial scatter plot relating economic growth to capital-account liberalization, 1975-89 (controlling for per-capita income, secondary education, quality of governmental institutions, and regional dummies for East Asia, Latin America, and sub-Saharan Africa). 
Investment/GDP and capital account liberalization 1975-89 - Rodrik 1998

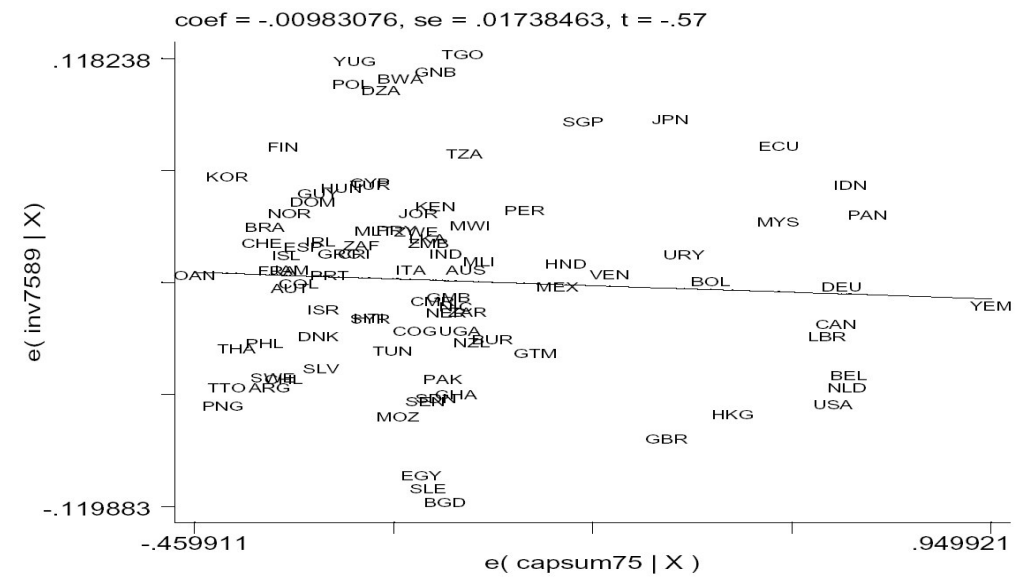

Figure 2: Partial scatter plot relating investment/GDP to capital-account liberalization, 1975-89 (controlling for per-capita income, secondary education, quality of governmental institutions, and regional dummies for East Asia, Latin America, and sub-Saharan Africa).

\section{ADVOCACY -SPECIAL INTERESTS, IDEOLOGY, NAÏVE ECONOMICS}

- FREE TRADE GOOD-THEREFORE FREE CAPITAL FLOWS GOOD

- BUT CAPITAL FLOWS, CAPITAL MARKETS ARE DIFFERENT

- Bhagwati 


\section{GENERAL THEORY}

- With limited information or incomplete markets (including imperfect risk markets), competitive equilibria are not, in general, constrained Pareto efficient.

- In a second-best world an intervention reducing one imperfection may have adverse side effects.

\section{RISK}

- WITH RISK, EVEN FREE TRADE MAY BE WELFARE DECREASING WITH IMPERFECT RISK MARKETS

- NEWBERY STIGLITZ-PARETO INFERIOR TRADE

- CRITICISM OF CAPITAL MARKET LIBERALIZATION IS THAT THEY EXPOSE COUNTRIES TO GREATER RISK 


\section{ADVOCATES CLAIMED THE CML WOULD REDUCE RISK}

- ALLOWED COUNTRIES TO BORROW IN TIMES OF NEED

- PRIMARY ARGUMENT FOR EAST ASIA—DIDN'T NEED MORE CAPITAL

- BUT IGNORED OBVIOUS EMPIRICAL EVIDENCE:

- CAPITAL FLOWS WERE PRO-CYCLICAL

- MAJOR CAUSE OF PROBLEMS IN LATIN AMERICA

- ALSO IGNORED BASIC THEORY

- BANKERS LEND TO PEOPLE WHO DON'T NEED MONEY

- Developing countries are exposed to exchange rate and interest rate fluctuations

- Short-term flows react to perceived adverse shocks thereby amplifying fluctuations. 
- Even if there is smoothing of small shocks, the resulting gains under concavity are smaller than the losses induced by large shocks.

\section{CML creates volatility}

- Reversal of flows:

- During the inflow the exchange rate appreciates

- After the outflow financial institutions are weakened, the depreciated exchange rate increases the cost of debt servicing

- Counter-cyclical monetary policy is constrained. 


\section{Why CML does not spur growth and investment}

- Higher output or consumption volatility imply a higher risk premium

- If investment depends on cash flow and balance-sheet effects, negative shocks can have particularly adverse effects

- Higher interest rate volatility exacerbates the previous effects

- Output and interest rate volatility decrease debt financing and equity markets are underdeveloped.

- Short-term capital is myopic and may determine myopic policies.

- Reserves may be unnecessarily high. 


\section{DISCIPLINE: ANOTHER REASON FOR ENHANCED GROWTH?}

- The "discipline of the market place" can be myopic and have adverse effects on longterm growth and stability

- Short term markets often look more at deficits, liabilities, not at "balance sheets"

\section{Interventions}

- GENERAL POINT: EXTERNALITIES ASSOCIATED WITH SHORT TERM CAPITAL FLOWS, EXTERNALITIES REQUIRE INTERVENTIONS

- Chile and Malaysia suggest that there can be successful capital market regulations. 


\section{IMF FINALLY LOOKS AT THE EVIDENCE}

- Macroeconomic impact of CML (Prasad et al., 2003)

- No evidence of a positive correlation between financial integration and economic growth.

- Countries that made the effort to become financially integrated faced more instability.

Total consumption annual growth rate volatility to income annual growth rate volatility (medians)

Prasad et al. (2003)

\begin{tabular}{|l|c|c|c|c|c|}
\hline & $1960-99$ & $1960 \mathrm{~s}$ & $1970 \mathrm{~s}$ & $1980 \mathrm{~s}$ & $1990 \mathrm{~s}$ \\
\hline $\begin{array}{l}\text { Industrial } \\
\text { countries }\end{array}$ & 0.67 & 0.75 & 0.56 & 0.61 & 0.58 \\
\hline $\begin{array}{l}\text { More } \\
\text { financially } \\
\text { integrated }\end{array}$ & 0.81 & 0.92 & 0.74 & 0.76 & 0.92 \\
$\begin{array}{l}\text { Less } \\
\text { financially } \\
\text { integrated }\end{array}$ & 0.80 & 0.95 & 0.68 & 0.82 & 0.84 \\
\hline $\begin{array}{l}\text { Total consumption = C + G. } \\
\text { Income = output + factor income flows + terms of trade effect. }\end{array}$ \\
\hline
\end{tabular}




\section{IMF SURPRISED}

- INCONSISTENT WITH "THEORY"

- BY WHICH THEY MEAN NEOCLASSICAL THEORY WITH PERFECTION INFORMATION

- But failures of neoclassical open economy theory already well documented

- The neoclassical theory (perfect information, perfect capital markets, perfect competition) cannot explain several stylized facts.

- Obstfeld and Rogoff's "major puzzles", failure of the interest rate parity, pro-cyclical nature of capital movements

\section{Imperfect information and rationality}

- Lessons from East Asia:

- Widespread credit rationing due to imperfect and asymmetric information

- Excessive leverage and the relevance of financial structure

- Market imperfections and irrationalities play a central role in economic fluctuations (irrational exuberance/pessimism) 


\section{Types of capital flows}

- If FDl's have a positive effect on growth, and the aggregate effect is nil, then shortterm flows have a negative effect.

\section{FDl's may not generate growth}

- FDl's include revenues from privatizations which may or may not be welfareincreasing

- Natural resource curse.

- Foreign banks acquiring domestic banks may reduce financing to SME's.

- Foreign banks may contract credit in the case of an adverse shock in the home country. 


\section{IMF BLAMES GOVERNANCE}

- Problems in identifying empirically the effect of good governance.

- Good governance does not eliminate information imperfections and irrationalities.

\section{FORMAL MODELS}

- EASY TO CONSTRUCT MODELS WITH CREDIT RATIONING, IMPERFECT CAPITAL MARKETS, OVERLAPPING GENERATIONS IN WHICH CAPITAL MARKET LIBERALIZATION LEADS TO INCREASED VOLATILITY, LOWER WELFARE 


\section{Regime changes and volatility}

- There are two states of nature: $\theta_{1}$ and $\theta_{2}$ ( $\theta_{1}$ is the bad state) following a Markov chain with constant transition probability $\pi$.

- In both states there are two projects: risky $(\mathrm{R})$ and safe (S). Both projects last two periods.

- Monitoring of project undertaken is impossible. Loans are variable rate.

- $\beta_{i}^{j}\left(r, r^{\prime}\right) ; j=S, R ; i=\theta_{1}, \theta_{2}$ is the expected return for the borrower of

- investment j

- undertaken in state $\mathrm{i}$

- when the interest rate changes from $r$ to $r$ ' in case of a regime change (if no change happens, then the interest rate will remain constant at $r$ )

- The outcome of the project depends on the state of nature in the second period. 
- Take the set of state-dependent interest rates $\left\{r_{1}, r_{2}\right\}_{i} ; i=\theta_{1}, \theta_{2}$ such that the safe project is incentive-compatible.

- Let $\rho_{\mathrm{i}}\left(r_{1}, r_{2}\right)$ be the expected return to the lender of a loan

- made in state $i=\theta_{1}, \theta_{2}$

- for given incentive-compatible $\left\{r_{1}, r_{2}\right\}$

- Let $\rho^{*}$ be the safe international rate of return and assume

$\operatorname{Max} \rho_{1}\left(r_{1}, r_{2}\right)<\rho^{*}<\operatorname{Min} \rho_{2}\left(r_{1}, r_{2}\right)$

- There are $\mathrm{M}^{*}$ safe projects each costing a dollar.

- Aggregate output is given by

$$
Y_{i}=[X+G+I] /\left[m+s\left(\rho_{i}\right)\right]
$$

- Where exports and government spending are fixed, $m$ is the marginal propensity to import and $s\left(\rho_{i}\right)$ is the marginal propensity to save $\left(s^{\prime}>0\right)$. 


\section{- Closed financial markets}

- $\rho$ adjusts to equate savings and investments.

- In the good state $\mathrm{I}=\mathrm{M}^{*}$.

- In the bad state $\mathrm{I}<\mathrm{M}^{*}$ and the interest rate is the maximum such that the safe investment is undertaken.

-There is no output variability

$$
Y_{i}=[X+G] / m ; i=\theta_{1}, \theta_{2}
$$

\section{- Open financial markets}

$-\mathrm{s}^{*}=\mathrm{s}\left(\rho^{*}\right)$

- In the good state all safe investment projects are undertaken; in the bad state there is no interest rate at which it is profitable to invest. 
- Opening the capital market lowers output in the bad state and may increase output in the good state if the country borrows abroad.

- Capital flows are pro-cyclical.

- The effect on consumption is ambiguous.

\section{Incomplete risk markets}

- Two-period OLG model

$$
\begin{aligned}
U^{\mathrm{j}}\left(\mathrm{c}_{1}, \mathrm{c}_{2}\right) & =\ln \left(\mathrm{c}_{1}\right)+\ln \left(\mathrm{c}_{2}\right) \\
\mathrm{c}_{1} & =\mathrm{w}_{\mathrm{t}}-\mathrm{s}_{\mathrm{t}} \\
\mathrm{c}_{2} & =\left(1+\mathrm{r}_{\mathrm{t}+1}\right) \mathrm{s}_{\mathrm{t}}
\end{aligned}
$$

- Foreigners only lend to enterprises.

- The international interest rate is variable. 


\section{Deterministic domestic technology}

- The production function is neoclassical

$$
Q_{t}=F\left(K_{t}, L_{t}\right)=L_{t} f\left(k_{t}\right)=f\left(k_{t}\right)
$$

- Capital depreciates completely each period.

- The closed economy

- the law of motion of capital is

$$
\mathrm{k}_{\mathrm{t}}=\mathrm{s}_{\mathrm{t}-1}=.5 \mathrm{w}_{\mathrm{t}-1}=.5 \mathrm{~g}\left(\mathrm{k}_{\mathrm{t}-1}\right)
$$

- The steady state is: $\mathrm{k}^{*}=.5 \mathrm{~g}\left(\mathrm{k}^{*}\right)$

\section{- The open economy:}

$-k_{t}=f^{\prime}-1\left(1+r_{t}\right) \equiv h\left(r_{t}\right)$

- The expected utility of a generation at time $t$ is $E_{t}[U]=-2 \ln (.5)+2 \ln \left(w_{t}\right)+E_{t}\left[\ln \left(1+r_{t+1}\right)\right]$

- The ex-ante expected utility is $E\left\{E_{t}[U]\right\}=-2 \ln (.5)+2 E\left[\ln \left(w_{t}\right)\right]+E\left[\ln \left(1+r_{t+1}\right)\right]$

- If the economy is at its steady state, CML unambiguously leads to an increase in consumption variability. 
- Impact on social welfare:

- Assume $E\left[\ln \left(1+r_{t}\right)\right]=\ln \left(1+r_{c}\right)$ and a utilitarian social welfare function.

- In the open economy $\left(\alpha_{t}\right.$ the income share of $\mathrm{K})$ :

$\partial w / \partial \ln (1+r)=-\alpha_{t} /\left(1-\alpha_{t}\right)=\left[\left.\left(d_{t} / d K_{t}\right)\right|_{\text {isoquant }}\right] k_{t}$ The effect on social welfare depends on $\partial\left[\left.\left(\mathrm{dL}_{\mathrm{t}} / \mathrm{dK}_{\mathrm{t}}\right)\right|_{\text {isoquant }}\right] \mathrm{k}_{\mathrm{t}} / \partial \ln \left(1+\mathrm{r}_{\mathrm{t}}\right)=\mathrm{A}\left[1-\Psi^{-1}\right]$

A $>0 ; \Psi$ the elasticity of substitution between $\mathrm{K}$ and $\mathrm{L}$

- If $\psi<1, \ln (w)$ is a concave function of $\ln \left(1+r_{t}\right)$ and social welfare is decreased.

- If the social welfare function is inequality/risk averse, welfare is reduced even if $\psi>1$ (provided it is not too large). 


\section{Stochastic domestic production}

- If $Q_{t}=\theta_{t} f\left(k_{t}\right)$, then $k_{t}=.5 \theta_{t-1} g\left(k_{t-1}\right)$

- In the closed economy:

$$
\begin{aligned}
E_{t} U^{j} & =-2 \ln .5+2 \ln w_{t}+E_{t} \ln \left(\theta_{t+1}\right) \\
& +\ln \left[f^{\prime}\left(w_{t} / 2\right)\right]
\end{aligned}
$$

- Assuming $E\left[\ln \left(\theta_{t}\right)\right]$ is a martingale,

$$
\begin{aligned}
E\left\{E_{t}\left[U^{j}\right]\right\} & =-2 \ln (.5)+3 E\left[\ln \left(\theta_{t}\right)\right] \\
& +2 E\left[\ln g\left(k_{t}\right)\right]+E\left[\ln f^{\prime}\left(.5 \theta_{t} g\left(k_{t}\right)\right)\right]
\end{aligned}
$$

- In the open economy:

$E_{t} U j=-2 \ln .5+2 \ln w_{t}+E_{t}\left[\ln \left(1+r_{t+1}\right)\right]$

- $\mathrm{k}_{\mathrm{t}}=\mathrm{h}\left(\mathrm{r}_{\mathrm{t}} / \theta_{\mathrm{t}}\right) ; \mathrm{w}_{\mathrm{t}}=\theta_{\mathrm{t}} \mathrm{g}\left[\mathrm{h}\left(\mathrm{r}_{\mathrm{t}} / \theta_{\mathrm{t}}\right)\right]$

- With constant international interest rate:

$$
\begin{aligned}
E\left\{E_{t} U^{j}\right\}= & -2 \ln (.5)+2 E\left[\ln \left(\theta_{t}\right)\right] \\
& +2 E\left[\ln g\left(h\left(r / \theta_{t}\right)\right)\right]+\ln (1+r)
\end{aligned}
$$


- CML allows for greater variability of wages (when $\theta$ is high the country can borrow more and vice versa)

- High wages today have no adverse effect on the interest rate at $t+1$

- If the social welfare function is sufficiently inequality/risk averse, social welfare is decreased.

- Can the access to more resources counteract the losses from greater variability?

- Consider a unitary elasticity technology and a utilitarian social welfare function.

- Assume that $E\left[\ln \left(1+r_{c}\right)\right]=\ln \left(1+r_{0}\right)$.

- Then $E\left[\ln \left(w_{c}\right)\right]=E\left[\ln \left(w_{o}\right)\right]$ and the expected utility at time $t$ is the same in the closed and open economy. 
- However, generational utility is

$$
\operatorname{Ln}\left(.5 w_{t}\right)+\ln \left(.5 w_{t}\left(1+r_{t+1}\right)\right)
$$

where $w_{t}$ and $r_{t+1}$ are negatively correlated in the closed economy.

- It follows that there is less utility variability and higher social welfare before CML.

- With CML: $\partial \ln (w) / \partial \ln \theta=1 /(1-\alpha)$

- Thus, variations in $\theta$ generate large variations in wages and therefore in lifetime utility, particularly if the share of labor is small. 
- In a closed economy life-time consumption of the young does not increase in tandem with productivity.

- Moreover, the benefits of a productivity shock are shared with future generations.

- With CML the interest rate does not depend on the country's own savings.

- Productivity shocks affect only the generation working at the time of the shock.

\section{FUTURE RESEARCH}

- Neoclassical open economy modelling is at a dead-end-too many puzzles that cannot be explained

- Theories of asymmetric information, imperfect risk markets hold open promise of an alternative open market macroeconomy

- Better descriptions of what has happened

- Markedly different policy prescriptions 